\title{
New approaches to the development of construction technologies
}

\author{
Sergey Zolotukhin ${ }^{1}$, Olga Kukina $^{1}$, Ekaterina Artemova ${ }^{1}$, Andrey Eremin ${ }^{1}$, Vladimir Volokitin $^{1}$, and Olga Volokitina $^{1}$ \\ ${ }^{1}$ Voronezh State Technical University, 84, 20 let Oktyabrya st., Voronezh 394006, Russia
}

\begin{abstract}
The paper presents data on the volume of materials consumed by builders and the carbon dioxide emissions that occur during this process. The reasons for the formation and volume of construction debris are considered. Recycling technologies currently used in the demolition of buildings are associated with crushing. The resulting concrete mix is used only for filling low-level earthworks due to the rapid carbonation of concrete surfaces. The scrap metal formed during crushing is used for remelting, polluting the atmosphere and requiring a large amount of energy. It is proved that due to the low economic and environmental efficiency, this method of recycling is a dead end. Studies have found that the constant increase in the strength of concrete and the absence of a decrease in the strength characteristics of reinforcing steels, stone materials, bricks, which are operated for a long time in favorable temperature and humidity conditions, allows them to be reused. General approaches have been developed that require changes in the existing technologies for the renovation of urban areas, the demolition of individual buildings and structures that currently exist. To reduce $\mathrm{CO} 2$ emissions and construction debris, it is enough to increase the volume of gentrification, reconstruction, major repairs, and re-profiling of the existing residential and industrial stock. When demolishing buildings, it is necessary to abandon the method of collapse of building structures with their further fragmentation. The method of piecemeal dismantling with repeated use of materials, products and structures (after determining their strength indicators by specialists), allows you to dramatically reduce the problems of construction debris and carbon dioxide emissions.
\end{abstract}

\section{Introduction}

The Kyoto Protocol and the Paris Climate Agreement of the United Nations Framework Convention on Climate Change require a reduction in global greenhouse gas emissions. The construction industry uses cement, lime, steel, brick, glass. The production of these materials leads to direct emissions of carbon dioxide into the Earth's atmosphere. The constant need for the development of urban areas inevitably leads to the demolition of old buildings and structures, while forming huge amounts of construction debris. Each country that conducts renovation works strives to most effectively stimulate the process of demolishing old buildings and takes a number of measures to do this: the use of targeted programs that ensure the investment of projects through the provision of subsidies, the provision of benefits to individuals for lending and tax fees [1-9]. But during the renovation, one important and acute issue is raised - the disposal of construction waste [10-14]. Thus, studies conducted in European countries prove that construction waste makes up almost a third of all generated waste $[5-7,15]$. According to the European Association for the Demolition of Buildings, more than 2.5 billion tons of construction debris are generated worldwide every year. Therefore, the rational use of construction waste is becoming one of the main directions for environmental protection. Mechanisms for the recycling and reuse of building materials began to be developed in the world about 20 years ago. To date, we can say that there is a whole industry of recycling of building materials. In developed countries, there is a policy to tighten the laws on burial sites and the formation of unauthorized landfills, creating conditions under which it becomes unprofitable to export waste to landfills. Therefore, recycling and reuse of old structures becomes not only environmentally beneficial, but also economically feasible [16-21]. The analysis of demolition technologies of buildings and structures shows the interdependence between the selected demolition technologies and the amount of waste generated. The most environmentally unsafe method is the removal of construction waste to landfills [22-29]. This method is most often used in mechanized and explosive demolition of buildings and structures, so it is now abandoned by most developed countries of the world [30-35]. The demolition of buildings leads to the formation of heterogeneous low-grade stone materials that do not have a uniform guaranteed strength [36-37]. The main volume of construction debris after the dismantling of the building is reinforced concrete, concrete and brick. Waste is sorted by special equipment. Large-sized blocks are crushed, and then processed in crushers installed directly on the site. The 
product of recycling of building materials is crushed stone, which is widely used for filling technological roads, filling the sinuses of pits, and drainage devices in swampy areas [38-44].

The proposed piecemeal disassembly of buildings using modern technology allowed us to reuse the resulting building structures and materials in the construction of low-rise buildings and the construction of the bases of intra-village roads, significantly reducing their cost [47]. Monolithic and precast-monolithic reinforced concrete structures, which were broken during the element-by-element disassembly, can be used as structural elements of foundations $[45,46]$.

Transportation of billions of tons of construction materials, including to landfills, leads to pollution of territories and the atmosphere. The reason for this situation is the conservatism of the use of traditional materials and technologies in construction. Therefore, the development of new approaches and construction technologies that contribute to sustainable development is an urgent task facing material scientists, technologists, and builders.

\section{Materials and methods}

The studies used statistical data on the production of building materials, demolition of buildings and structures, carbon dioxide emissions, and the formation of construction debris.

When determining the strength indicators, experimental data obtained during the survey of several buildings and structures that are in various operating conditions for a long time were used.

The strength of concrete and bricks in load-bearing building structures was determined by the impact pulse method according to GOST 22690-2015 " Concrete. Determination of strength by mechanical methods of non-destructive testing" (impact-pulse strength meter " Onyx-2.6). Foundation slabs, concrete foundation blocks, reinforced concrete columns, crossbars, floor slabs and silicate bricks were subjected to tests. The concrete test sites for determining the strength were located:

- in places of the lowest concrete strength, previously determined by the expert method;

- in zones and elements that determine their loadbearing capacity;

- in places with defects and damage that may indicate a reduced strength of the concrete.

To determine the steel grade of construction trusses, metal samples were selected for mechanical testing and chemical analysis. The mechanical properties of the steel were determined by testing the surface layer of the metal samples for Rockwell hardness using the TK-2 device in accordance with GOST 9013-59 "Rockwell hardness test". The chemical analysis of the steel was carried out in accordance with GOST 22762-77 " Metals and alloys. Method for measuring the yield strength by pressing the ball".

Tests of strength and deformation characteristics of reinforcing steel were carried out in accordance with
GOST 1497-84. " Metals. Methods of tensile testing" on the Instron 5982 universal electromechanical test system with a load error of $\pm 0.5 \%$

\section{Results}

The result of statistical studies shows:

1) of the total carbon dioxide emissions (35 - 50 billion US dollars). $\mathrm{m} 3$ of man-made $\mathrm{CO} 2$ emissions) the construction industry emits up to 15 billion tons annually. In addition, the construction industry consumes more than 5 billion tons of clean water and 800 million $\mathrm{m} 3$ of wood;

2) a big problem in the construction industry is the demolition of buildings and structures, which leads annually to the formation of more than 2.5 billion tons of construction debris according to the European Association for the Demolition of Buildings [48].

Studies of the strength indicators of materials and structures of buildings that fall under demolition are given below.

The results of determining the class of concrete with a service life of 52 years in terms of strength are presented in Table 1

Table 1. Results of determining the concrete strength class.

\begin{tabular}{|c|c|c|c|c|}
\hline $\begin{array}{l}\text { Name of the } \\
\text { structural element }\end{array}$ & $\begin{array}{l}\frac{\underline{\text { Actual }}}{\text { grade of }} \\
\frac{\text { concrete }}{\mathrm{kg} / \mathrm{cm} 2 /} \\
\underline{\mathrm{Mpa}}\end{array}$ & $\begin{array}{c}\text { Mean } \\
\text { square } \\
\text { deviation }\end{array}$ & $\begin{array}{l}\text { Coefficient } \\
\text { of variation }\end{array}$ & $\begin{array}{l}\text { Concrete } \\
\text { class }\end{array}$ \\
\hline $\begin{array}{l}\text { Prefabricated } \\
\text { reinforced } \\
\text { concrete } \\
\text { foundation plate } \\
\text { (quantity } 30 \text { pcs.) }\end{array}$ & $\underline{206}$ & 2.187 & 10.6 & 15 \\
\hline $\begin{array}{l}\text { Precast concrete } \\
\text { foundation blocks } \\
\text { (quantity } 30 \text { pcs) }\end{array}$ & $\frac{143}{14.4}$ & 1.344 & 12.1 & 10 \\
\hline $\begin{array}{c}\text { reinforced } \\
\text { concrete column } \\
\text { (quantity } 30 \mathrm{pcs} \text { ) }\end{array}$ & $\frac{267}{26.8}$ & 2.85 & 10.6 & 20 \\
\hline $\begin{array}{c}\text { Prefabricated } \\
\text { reinforced } \\
\text { concrete floor } \\
\text { crossbar (quantity } \\
30 \text { pcs) }\end{array}$ & $\frac{217}{21.7}$ & 2.433 & 11.2 & 15 \\
\hline $\begin{array}{l}\text { Prefabricated } \\
\text { multi-cavity } \\
\text { reinforced } \\
\text { concrete floor } \\
\text { slab (quantity } 30 \\
\text { pcs) }\end{array}$ & $\frac{253}{25.3}$ & 2.771 & 10.9 & 20 \\
\hline
\end{tabular}

The actual physical and mechanical characteristics of the masonry of the load-bearing wall of the building with a service life of 52 years are given in Table 2 . 
Table 2. Results of the control of the strength and uniformity of the masonry materials of the load-bearing walls of the building.

\begin{tabular}{|c|c|c|c|}
\hline $\begin{array}{c}\text { The name of } \\
\text { the structural } \\
\text { element }\end{array}$ & $\begin{array}{c}\text { Average } \\
\text { arithmetic, Xsr, } \\
\mathrm{kgf} / \mathrm{cm} 2\end{array}$ & $\begin{array}{l}\text { Average } \\
\text { square } \\
\text { deviation, } \\
\mathrm{kgf} / \mathrm{cm} 2\end{array}$ & $\begin{array}{c}\text { Coefficient of } \\
\text { variation, } \\
\%\end{array}$ \\
\hline Silicate brick & 128 & 14 & 11.7 \\
\hline
\end{tabular}

The actual physical and mechanical characteristics of steel structures with a service life of 71 years are given in Table 3.

Table 3. Mechanical properties of steel.

\begin{tabular}{|c|c|c|}
\hline $\begin{array}{c}\text { Countings on } \\
\text { the indicator }\end{array}$ & $\begin{array}{c}\text { Average value of } \\
\text { hardness HR }\end{array}$ & $\begin{array}{c}\text { Number of hardness HR, } \\
\text { reduced to hardness HB, } \\
\mathrm{kgf} / \mathrm{mm} 2\end{array}$ \\
\hline $89.6-90.5$ & 90.1 & 179.4 \\
\hline
\end{tabular}

The strength and deformation characteristics of reinforcing steel that has begun to corrode, with a service life of 64 years, are presented in Table 4.

Table 4. Strength and deformation characteristics of reinforcing steel.

\begin{tabular}{|c|c|c|}
\hline $\begin{array}{c}\text { Yield strength }(0.2 \%), \\
\mathrm{MPa}\end{array}$ & $\begin{array}{c}\text { Tensile stress, } \\
\mathrm{MPa}\end{array}$ & Elongation, \% \\
\hline 341.00 & 503.76 & 20.68 \\
\hline
\end{tabular}

\section{Discussion}

The main reasons for the formation of the carbon footprint in the construction industry is the carbon dioxide emissions arising from the production of cement, lime, steel, glass, ceramics, where the emission occurs as a result of chemical reaction of decomposition of calcium carbonates in the firing:

$$
\mathrm{CaCO}_{3}=\mathrm{CaO}+\mathrm{CO}_{2} \uparrow, \Delta \mathrm{H}>0 .
$$

In the production of gypsum binders that can replace cement, carbon emissions do not exist, the technological chain of production of less energy-intensive.

The analysis of the strength indicators given in Tables 1-4 and the data given in $[49,50]$ shows that the strength of concrete of reinforced concrete structures, bricks, reinforced steel of reinforced concrete structures and steel structures operated in favorable temperature and humidity conditions does not fall, and concrete even increases. Based on the above, we can draw the following conclusions.

1. To reduce $\mathrm{CO} 2$ emissions and reduce the amount of construction debris, it is sufficient to increase the volume of reconstruction, major repairs, repurposing, existing residential and industrial stock, as well as industrial buildings and structures.

2. The collapse method used in the demolition of emergency facilities after determining the strength and environmental characteristics of materials, products and structures must be abandoned.

3. Crushing of concrete and reinforced concrete structures is inefficient, energy-consuming and unecological due to the following factors:
- when crushing reinforced concrete and remelting steel reinforcement, a significant amount of energy is consumed;

- the concrete rubble undergoes rapid carbonization of the newly formed concrete surfaces, as a result of which the resulting materials have reduced water resistance;

- when melting 1 ton of steel, 1.5 tons of carbon dioxide is emitted.

Research conducted at the Voronezh State Technical University shows a constant increase in the strength of cement concretes of building structures during its operation under normal conditions.

At the same time, the service life of demolished buildings ranges from 30 to 70 years, although, according to various reference literature, their service life should be 100-175 years. The actual service life of Roman concrete and brick is thousands of years.

It is easy to assume that the dismantled structures and materials can be reused without crushing after inspection and appropriate justification. This will allow, given the volume of demolition, dramatically improve the environmental problem and reduce the cost of building low-rise buildings.

Demolition of buildings should be carried out using a new approach, which includes the following steps.

The first stage: piecemeal dismantling of buildings with separate storage of the resulting building materials, products and structures.

The second stage: determination by specialists of the residual strength characteristics of products and structures with rejection and subsequent justification of the possibility of their reuse as various elements of lowrise buildings and structures: foundations, wall materials, floor slabs, coatings, fixed formwork for stone, concrete and reinforced concrete structures.

The third stage: designing buildings with reusable products and structures.

The fourth stage: management of the construction of such structures and constant engineering control of the quality and technology of construction.

As noted earlier, the demolition of buildings is accompanied by the appearance of crushed stone materials in the form of brick, concrete, reinforced concrete, cinder blocks. After conducting research on the selection of compositions and technologies, we proposed to use these materials to strengthen clay soils in construction under difficult hydrogeological conditions using bulk cementation of soils, where they are often used as an active porous aggregate [51].

In recent years, the authors have obtained patents of the Russian Federation for methods of constructing stepped foundations, solid box-section slab foundations, and ribbon foundations using ribbed floor slabs that appeared during the element-by-element dismantling of industrial buildings and volumetric soil reinforcement [52-54]. The results of the patent developments were used in practice in strengthening the soil of the bases, flooded areas, and the construction of dozens of foundations of low-rise buildings, which led to a 4-6fold reduction in the cost of foundation construction. Thousands of tons of construction debris did not fall into 
landfills, but carbon dioxide emissions-into the earth's atmosphere.

\section{Conclusion}

The main reasons for the formation of carbon dioxide emissions generated during the production of basic building materials are analyzed. The volume of construction debris generated by traditional methods of demolition of buildings and structures is determined. A number of areas have been identified that allow us to use new approaches to the construction industry. These approaches will make it possible to create construction waste-free technologies that ensure the sustainable development of urban areas by reducing the volume of demolition and switching to the piecemeal dismantling of buildings, replacing technologies using cement with gypsum materials, including those obtained using nonburning technologies.

Studies of the strength of bricks, concrete, reinforced concrete structures, and reinforcing steels made of reinforced concrete structures that have been used in favorable conditions for 40 years or more have shown a certain increase in the strength of concrete and bricks.

Reinforced concrete structures that are obtained during the piecemeal dismantling of buildings can and should be used as load-bearing structures for their intended purpose, and structures that have received defects should be used in the construction of foundations and other structures of low-rise buildings (with appropriate justification).

The novelty of this technology is confirmed by patents of the Russian Federation.

The use of the technologies discussed above leads to a reduction in the cost of construction work due to the reuse of materials and structures, as well as an improvement in the environmental situation.

\section{Recommendations}

The conducted research shows the need to increase the volume of gentrification, reconstruction, and major repairs of the residential and industrial stock. In the case of new construction, it is necessary to replace, where possible, cement materials, products and structures with gypsum, including those obtained by non-firing technology from multi-tonnage construction waste.

It is necessary to continue research on non-burning technologies with the reuse of materials formed during the demolition of buildings. It is necessary to increase the volume of piecemeal dismantling of buildings with the sorting of the resulting materials, products and structures and their re-use in the construction of low-rise objects.

There was a need for the emergence and teaching of new disciplines at different levels of education of construction specialties.

The authors express their gratitude to the staff of the Center for Collective Use named after Professor Yu. M. Borisov VSTU and Associate Professor Shmelev G. D. for the materials and advice provided.

\section{References}

1. J.L.K. Nussholz, F.N. Rasmussen, L. Milios, Circular building materials: Carbon saving potential and the role of business model innovation and public policy, Resources, Conservation and Recycling, 141, 308-316 (2019) DOI: 10.1016/j.resconrec.2018.10.036

2. J. Charytonowicz, M. Skowroński, Reuse of building materials, Procedia Manufacturing, 3, 1633-1637 (2015) DOI: 10.1016/j.promfg.2015.07.456

3. M. Honic, I. Kovacic, H. Rechberger, Improving the recycling potential of buildings through Material Passports (MP): An Austrian case study, Journal of Cleaner Production, 217, 787-797 (2019) DOI: $10.1016 /$ j.jclepro.2019.01.212

4. N. Johansson, H. Corvellec, Waste policies gone soft: An analysis of European and Swedish waste prevention plans, Waste Management, 77, 322-332 (2018) DOI: 10.1016/j.wasman.2018.04.015

5. S. Huuhka, T. Kaasalainen, J.H. Hakanen, J. Lahdensivu, Reusing concrete panels from buildings for building: Potential in Finnish 1970s mass housing, Resources, Conservation and Recycling, 101, 105-121 (2015) DOI: 10.1016/j.resconrec.2015.05.017

6. M. Arm, O. Wik, C.J. Engelsen, M. Erlandsson, O. Hjelmar, M. Wahlström, How does the European recovery target for construction $\&$ demolition waste affect resource management?, Waste and Biomass Valorization, 8, 1491-1504 (2017) DOI: 10.1007/s12649-016-9661-7

7. A. Yazdanbakhsh, A bi-level environmental impact assessment framework for comparing construction and demolition waste management strategies, Waste Management, 77, 401-412 (2018) DOI: 10.1016/j.wasman.2018.04.024

8. G.A. Blengini, Life cycle of buildings, demolition and recycling potential: a case study in Turin, Italy, Building and Environment, 44 (2), 319-330 (2009) DOI: 10.1016/j.buildenv.2008.03.007

9. I.Z. Bribián, A.V. Capilla, A.A. Usón, Life cycle assessment of building materials: comparative analysis of energy and environmental impacts and evaluation of the eco-efficiency improvement potential, Building and Environment, 46 (5), 1133 1140 (2011) DOI: 10.1016/j.buildenv.2010.12.002

10. H. Wu, J. Zuo, G. Zillante, J. Wang, H. Yuan, Status quo and future directions of construction and demolition waste research: A critical review, Journal of Cleaner Productio, 240 (2019) DOI: 10.1016/j.jclepro.2019.118163

11. L.C.M. Eberhardt, H. Birgisdottir, M. Birkved, Potential of circular economy in sustainable buildings, IOP Conference Series: Materials Science and Engineering, 471 (2019) DOI: 10.1088/1757- 899X/471/9/092051 
12. F. Aras, Monitoring the dynamic properties of a nine-story reinforced concrete building during its demolition, Structural control \& Health Monitoring, 26(11) (2019) DOI: 10.1002/stc.2456

13. O.Bukharova, S. Stepashin, Head of the Supervisory Board of the housing reform assistance Fund, talks about the resettlement program, Russian newspaper, 7724 (261) (2018)

14. B. Yu, J. Wang, J. Li, J. Zhang, Y. Lai, X. Xu, Prediction of large-scale demolition waste generation during urban renewal: A hybrid trilogy method, Waste Management, 20

15. J.L.K. Nussholz, F.N. Rasmussen, L. Milios, Circular building materials: Carbon saving potential and the role of business model innovation and public policy, Resources, Conservation and Recycling, 141, 308-316 (2019) DOI: 10.1016/j.resconrec.2018.10.036

16. S. Sakai, R. Poudel, M. Asari, T. Kirikawa, Disaster waste management after the 2016 Kumamoto Earthquake: A mini-review of earthquake waste management and the Kumamoto experience, Waste Management and Research, 37, 247-260 (2019) DOI: 10.1177/0734242X18815948

17. L.P. Rosado, P. Vitale, C.S.G. Penteado, U. Arena, Life cycle assessment of construction and demolition waste management in a large area of São Paulo State, Brazil, Waste Management, 85, 477-489 (2019) DOI: 10.1016/j.wasman.2019.01.011

18. K. Hu, Y. Chen, F. Naz, C. Zeng, S. Cao, Separation studies of concrete and brick from construction and demolition waste, Waste Management, 85, 396-404 (2019) DOI: 10.1016/j.wasman.2019.01.007

19. J.L.K. Nussholz, F. Nygaard Rasmussen, L. Milios, Circular building materials: Carbon saving potential and the role of business model innovation and public policy, Resources, Conservation and Recycling, 141, 308-316 (2019) DOI: 10.1016/j.resconrec.2018.10.036

20. A.O. Gurfov, The analysis of foreign experience of recycling construction waste, Collection of articles II International scientific and practical competition, 18-22 (2016)

21. A.N. Gajkalov, E.A. Potapenko, More efficiently of fencing cellular concrete in wall structures civil buildings, Russian Journal of Building Construction and Architecture, Materials of the interregional scientific-practical conference "High technologies in ecology", Penza, Science and Enlightenment, 1, 58-61 (2012)

22. M.S. Budnik, T.S. Karpova, Dismantling of buildings and secondary use of materials, Materials of the 57th student scientific and technical conference of PNU Institute of civil engineering, Khabarovsk, 17-27 April 2017, Khabarovsk, 48-51 (2017)

23. A.A. Bakhtina, T.V. Ohlopkova, The use of recycled materials for a green future [Electronic resource], Modern research and development 3:4(21), 29-30 (2018) Available at: https:// elibrary.ru/download/elibrary_36324318_86423318 . pdf

24. S.N. Zolotukhin, V.I. Lugansky, N.G. Nazarenko, A.I. Demidenko, K.V. Makarychev, M.I. Borisova, et all, Reuse of reinforced concrete building elements in foundation structures, Chemistry, physics and mechanics of materials, 1 (20), 72-91 (2019)

25. E.A. Barsuk, Secondary use of building materials in the black earth region, The future of science 2019, Collection of scientific articles of the $7 \mathrm{th}$ international youth scientific conference, Kursk, 25-26 April 2019, Kursk, 11-13 (2019)

26. K.A. Slautina, M.M. Zhukov, Reuse and recycling of building materials, for example concrete with a light filler, Technical Sciences: problems and solutions, The proceedings of the XXIII international scientific-practical conference. Moscow, 21 May 2019, Moscow, Internauka publ., 100-103 (2019)

27. V.V. Andrienko, D.H. Galaeva, Application area of waste building materials, Safe and comfortable city, Collection of scientific papers on the materials of the I international scientific-practical conference of young scientists, Oryol, 29 September 2017, Oryol, 179-182 (2017)

28. D.S. Lukashevich, A.V. Turov, Building materials based on industrial wastes, Russian cities: problems of construction, engineering, landscaping and ecology Collection of articles XXI International scientific and practical conference. Penza, 16-17 April 2019, Penza, RIO PGAU, 70-72 (2019)

29. A.A. Lukash, N.P. Lukutsova, Effective building materials from industrial waste for housing, Vestnik of Volga State University of Technology, Series: Materials, Constructions, Technologies, 2, 26-37 (2017)

30. I.N. Tikhonova, S.H. Lega, Environmental problems of education and utilization of msw and building wastes in the region of caucasus Mineralnye vody region, On-line Scientific \& Educational Bulletin "Health \& education millennium", 19 (7), 49-53 (2017) DOI: 10.26787/nydha-2226-7417-2017-19-7-49-53

31. T.V. Kudryashova, A.A. Balanina, M.A. Svezhentseva, Problems of utilization of building wastes and prospects of their solution, Actual problems and prospects of social and economic development of modern Russia, Collection of articles of the all-Russian scientific and practical conference, 57-61 (2017)

32. A.M. Krygina, N.M. Krygina, On the issue of housing real estate reproduction on the basis of recycling of construction industry waste, Russian Journal of Housing Research, 5 (3), 353-366 (2018)

33. E.M. Bodenko, A.M. Perepechenov, Geoecological assessment of the method of collection and removal of construction waste in the city in preparation for demolition, Natural and technical Sciences, 5 (119), 143-148 (2018)

34. V.N. Lyutov, M.S. Baranovskaya, Features and prospects of modern technology of recycling of 
reinforced concrete products in housing construction, Polzunovsky almanac, 1, 139-142 (2016)

35. G.G. Lunev, Assessment of economic effect of processing of constructional secondary construction resources at the enterprises, Ecological systems and devices, 2, 49-55 (2015)

36. F. Agrela, A. Barbudo, A. Ramírez, J. Ayuso, M.D. Carvajal, J.R. Jiménez, Construction of road sections using mixed recycled aggregates treated with cement in Malaga, Spain, Resources, Conservation and Recycling, 58, 98-106 (2012) DOI: 10.1016/j.resconrec.2011.11.003

37. J.R. Jimenez, J. Ayuso, F. Agrela, M. López, A.P. Galvín, Utilisation of unbound recycled aggregates from selected CDW in unpaved rural roads, Resources, Conservation and Recycling, 20

38. J.R. Jiménez, J. Ayuso, M. López, J.M. Fernández, J. De Brito, Use of fine recycled aggregates from ceramic waste in masonry mortar manufacturing, Construction and Building Materials, 40, 679-690 (2013) DOI: 10.1016/j.conbuildmat.2012.11.036

39. J. Solís-Guzmán, M. Marrero, M.V. MontesDelgado, A. Ramírez-de-Arellano, A Spanish model for quantification and management of construction waste, Waste Management, 29 (9), 2542-2548 (2009) DOI: 10.1016/j.wasman.2009.05.009

40. K. Grigoriadis, M. Whittaker, M. Soutsos, W. Sha, L. Napolano, A. Klinge et all, Improving the recycling rate of the construction industry, Fifth International Conference on Sustainable Construction Materials and Technologies, 1 (2019) DOI: 10.18552/2019/ IDSCMT5044

41. J. Chen, Y. Su, H. Si, J. Chen, Managerial areas of construction and demolition waste: a scientometric review, International Journal of Environmental Research and Public Health, 15 (11) (2018) DOI: 10.3390/ijerph15112350

42. E. Iacovidou, P. Purnell, M.K. Lim, The use of smart technologies in enabling construction components reuse: A viable method or a problem creating solution?, Journal of Environmental Management, 216, 214-223 (2018) DOI: 10.1016/j.jenvman.2017.04.093

43. T.M. Rose, K. Manley, D. Agdas, A conceptual framework to investigate the adoption of on-site waste management innovation in Australian building projects, 2016 Portland International Conference on Management of Engineering and Technology (PICMET), 1830-1837 (2017) DOI: 10.1109/PICMET.2016.7806745

44. S. Guignot, S. Touzé, F. Von der Weid, Y. Ménard, J. Villeneuve, Recycling construction and demolition wastes as building materials: a life cycle assessment, Journal of Industrial Ecology, 19 (6), 1030-1043 (2015) DOI: 10.1111/jiec.12262

45. A. Arulrajah, M.M. Disfani, S. Horpibulsuk, C. Suksiripattanapong, N. Prongmanee, Physical properties and shear strength responses of recycled construction and demolition materials in unbound pavement base/subbase applications, Construction and Building Materials, 58, 245-257 (2014) DOI: 10.1016/j.conbuildmat.2014.02.025

46. J.R. Jiménez, J.R. Jiménez, F. Agrela, J. Ayuso, M. López, A comparative study of recycled aggregates from concrete and mixed debris as material for unbound road sub-base, Materiales de Construccion, 61, 289-302 (2011) DOI: $10.3989 / \mathrm{mc} .2010 .54009$

47. J. Zhang, F. Gu, Y. Zhang, Use of buildingrelated construction and demolition wastes in highway embankment: Laboratory and field evaluations, Journal of cleaner production, 230, 1051-1060 (2019) DOI: 10.1016/j.jclepro.2019.05.182

48. S.A. Kolodyazhny, S.N. Zolotukhin, A.A. Abramenko, E.A. Artemova, Demolition of buildings and the use of materials generated during the renovation of urban areas, Vestnik MGSU, Monthly Journal on Construction and Architecture, 15 (2), 271-293 (2020)

49. G.D. Shmelev, E.A. Kryuchkova, A.K. Episheva, Justification of the possibility of reuse of building materials and structures, Housing and communal infrastructure, 1 (8), 25-35 (2019)

50. G.D. Shmelev, M.S. Kononova, N.A. Maleva, Methodology for assessing the technical condition, forecasting and justification of the residual service life of building structures, Housing and communal infrastructure, 2 (9), 34-42 (2019)

51. S.N. Zolotukhin, A.A. Abramenko, O.B. Kukina, A.Yu. Vyazov, A.S. Lobosok, Method of volumetric cementation of soils, Patent for the invention RU 2656656 C2, 2015149374 (6 June 2018)

52. S.A. Kolodyazhny, S.N. Zolotukhin, A.A. Abramenko, O.B. Kukina, A.Yu. Elm, A.S. Lobosok, V.I. Milovanova, A method for manufacturing solid slab foundations of box-shaped cross-section from ribbed floor slabs

53. Patent for the invention RU $2647521 \mathrm{C} 1$, 16.03.2018, 2017107309 (6 March 2017)

54. S.A. Kolodyazhny, S.N. Zolotukhin, A.A. Abramenko, O.B. Kukina, A.Yu. Vyazov, A.S. Lobosok, V.I. Milovanova, Method for the construction of a stepped foundation using ribbed floor slabs (coverings). Patent for the invention RU 2647521 C1, 2017107309 (16 March 2018)

55. S.A. Kolodyazhny, S.N. Zolotukhin, G.D. Shmelev, V.Ya. Mishchenko, A.A. Abramenko, A.G. Chigarev, A.S. Lobosok, E.A. Artemova, I.A. Potekhin, A method for making a tape foundation from thin-walled reinforced concrete slabs with filling the sinuses with compacted soil or ground concrete, Patent for the invention RU $2734504 \mathrm{C} 1$, 19.10.2020, 2019133432 (21 October 2019) 